\title{
Influence of elastic stresses and temperature on the dislocation unpinning from the stoppers in $\mathrm{KCl}$ crystals
}

\author{
G.A.Petchenko, A.M.Petchenko \\ A. Beketov Kharkiv National University of Urban Economy, \\ 12 Revolution St., 61002 Kharkiv, Ukraine
}

Received January 19, 2015

Impulse echo-method was applied to investigate, in the temperature range from 300 to $430 \mathrm{~K}$ at $7.5 \mathrm{MGz}$ frequency, the dislocation absorption $\alpha_{d}(\sigma)$ in $\mathrm{KCl}$ crystals as a function of statistic loading in the quasi-elastic strain range. It has been found that the temperature increase at stresses $\sigma<\sigma_{t}\left(\sigma_{t}\right.$ is the yield strength of a crystal) leads to the intensive dislocation unpinning). Consequently, concentration of stoppers, controlling their motion, sharply decreases and the effective length of oscillating dislocation segments increases. As a result of the experimental data processing the energy of the impurity atom binding with dislocation $U_{0}$ and quantity $L$ characterizing a mean size of the dislocation cell was calculated. The experimental results were discussed within the framework of known dislocation theories.

Keywords: dislocation mobility, absorption, sound attenuation, quasilastic, dislocation density, internal friction, straining, slip plane, pinning centers, static ladening.

Импульсным эхо-методом на частоте 7,5 МГц в интервале температур 300-430 К изучена зависимость дислокационного поглощения ультразвука $\alpha_{d}(\sigma)$ в кристаллах $\mathrm{KCl}$ от величины статического нагружения в квазиупругой области деформаций. Выяснено, что повышение температуры при напряжениях $\sigma<\sigma_{t}\left(\sigma_{t}-\right.$ предел текучести кристалла) приводит к интенсивному раскреплению дислокаций. Вследствие этого концентрация стопоров, контролирующих их движение резко снижается, а әффективная длина колеблющихся дислокационных сегментов увеличивается. При обработке экспериментальных результатов рассчитана величина энергии связи примесного атома с дислокацией $U_{0}$, а также величина $L$, характеризующая средний размер дислокационной ячейки. Результаты опытов обсуждены в рамках существующих дислокационных теорий.

Вплив пружних навантажень і температури на процеси відкріплення дислокацій від стопорів у кристалах KCl. Г.О.Петченко, О.М.Петченко.

Імпульсним ехо-методом на частоті 7,5 МГц в інтервалі температур 300-430 К вивчена залежність дислокаційного поглинання ультразвуку $\alpha_{d}(\sigma)$ у кристалах $\mathrm{KCl}$ від величини статичного навантаження у квазіпружній області деформацій. 3'ясовано, що підвищення температури при напрузі $\sigma<\sigma_{t}\left(\sigma_{t}-\right.$ границя плинності кристала) призводить до інтенсивного розкріплення дислокацій. Внаслідок цього концентрація стопорів, що контролюють ї рух, різко знижується, а ефективна довжина дислокаційних сегментів збільшується. При обробці експериментальних результатів розраховано величину енергії зв'язку домішкового атома 3 дислокацією $U_{0}$, а також величину $L$, що характеризує середній розмір дислокаційної комірки. Результати дослідів обговорено в рамках існуючих дислокаційних теорій. 


\section{Introduction}

It is well known that in crystals the mobility of dislocations is limited by presence of stoppers slowing down their motion under applied external stresses. Dislocation network nodes refer to strong pinning centers, while individual impurity atoms, radiation damage centers refer to the weaker pinning centers. Reviews [1-4] show that processes of the dislocation unpinning due to the stress $\sigma$ and temperature $T$ changing have been studied usually by method of the amplitude-dependent internal friction in the kilohertz frequency band, as well as, by considering the individual dislocation mobility [3] or by measuring the plastic strain rate in the sample under different loading conditions [4]. Further the measured characteristics were used to evaluate activation energy $U$ and activation volume $\gamma$ and their dependences on $\sigma$ and $T$ and to reveal the mechanisms determining the plastic strain process. As the data obtained by these methods have been processed without taking into account the dislocation structure change, in particular, intensive nucleation and motion of the new dislocations, the derived results are insufficiently correct [4]. To obtain reliable experimental results the mobile dislocation density should be unchangeable during measuring the parameters of $U$ and $\gamma$. Note, that dislocation separation from the weak stoppers is possible even under the light external actions. It means that the weak stopper counteractions to the dislocation motion should be investigated in the quasi-elastic strain range.

In this connection for solving such problems the urgency of the method of high-frequency amplitude-independent internal friction is obvious. Here acoustic signal of the low amplitude $\left(\varepsilon \sim 10^{-7}\right)$, passing through the elastically strained crystal only controls the changes in its dislocation structure but has no influence on the appearance and behavior of the processes themselves [5].

Such a high-sensitivity method is suitable for investigation of processes of the dislocation separation from the stoppers directly in the elastic strain range, where the dislocation density invariability in crystals is provided.

Note that idea of conducting experiments in the elastic strain range was first realized in [5] on the high-purity copper samples. By checking the own model of thermoactivated dislocation separation from the stoppers the authors of [5] have succeeded in determin- ing the temperature dependence of the dislocation segment length and pinning point concentrations, as well as, in evaluating the energy of dislocation binding with the pinning center etc. Later the similar precision investigations were carried out only two times - on the CsI [6] and $\mathrm{KBr}$ [7] crystals. However, experimentally obtained data are insufficient to make a generalized analysis on the problem under consideration.

The purpose of this study is to continue similar investigations on the $\mathrm{KCl}$ single crystals. We suppose that due to the low Debye temperature $(\Theta=235 \mathrm{~K})$ the dislocation pinning effect can clearly reveal themselves at relatively low test temperatures.

\section{Experimental}

In this study the acoustic impulse echomethod was applied to investigate the dislocation ultrasonic $\alpha_{d}$ absorption in $\mathrm{KCl}$ single crystals as a function of the statistic loading $\sigma$ in 300-430 $\mathrm{K}$ temperature range. The value of $\alpha_{d}$ was measured by the superimposed exponent method on 7.5 $\mathrm{MHz}$ longitudinal wave using the original measuring device applied in [6,7]. The test samples of $10^{-4}$ wt $\%$ purity and size of $17 \times 17 \times 23 \mathrm{~mm}^{3}$ were obtained by chipping them along the cleavage plane $\langle 100\rangle$. The samples obtained were treated by grinding and polishing to achieve nonparallelism of the work surfaces of about $\pm 1 \mu \mathrm{m} / \mathrm{cm}$. Then the prepared samples were annealed in the muffle furnace MP-2UM for $\sim 12 \mathrm{~h}$ at temperature of 0.8 $T_{\text {melt }}\left(T_{\text {melt }}=770^{\circ} \mathrm{C}\right)$ with subsequent slow cooling up to the room temperature. Hightemperature liquid VKJ-94 was applied as a transition layer between the piezoelectric transducer and the sample.

Experiments were carried out by the following scheme. Using a specially designed furnace with electronic control a given test temperature of the samples was set and strictly maintained. The temperature was measured with a differential copper-constantan thermocouple. After reaching the required temperature an initial attenuation $\alpha_{0}$ at $\sigma=0$ was measured. Then the sample was step-by-step loaded by compression in the tensile-testing machine of "Instron" type at strain rate of $\sim 10^{-5} \mathrm{~s}^{-1}$ in the range of stresses $\sigma=(0 \div 7) \cdot 10^{5} \mathrm{~Pa}$. To avoid the point defect redistribution under applied load action the time of each loading was $15 \mathrm{~s}$. After each stop of the machine rod the quantities $\alpha_{d}$ and $\sigma$ were measured. The sample was unloaded when the indicated 
loading range was over. It was found that after the sample unloading the quantity $\alpha_{d}$ returned to its initial value at the given temperature that evidence on the elastic character of the sample loading. This has been confirmed by absence of strain stress on the chart of the recorder KSP-4 at each stop of machine movable clamps in the indicated range of temperatures and stresses.

It is well known that the measured ultrasonic attenuation $\alpha$ in crystals-dielectrics includes, besides the dislocation loss $\alpha_{d}$, the apparent loss $\alpha_{\text {theor }}$. Among them the main are the diffraction loss and the loss caused by the non-parallelism of the sample work surfaces.

In this connection a need has arisen to derive correctly the dislocation component from the measured attenuation. Analysis performed within the framework of the theory [8] has shown that the dominant contribution in the apparent loss is made by the diffraction loss $\alpha_{T}$ theor $=0.15 \mathrm{Db} / \mu \mathrm{s}$ and the contribution from other above-mentioned losses is negligibly low.

\section{Results and discussion}

Experimental dependences $\alpha_{d}(\sigma)$, obtained at temperatures $300,340,385$ and $430 \mathrm{~K}$ are presented in Fig. 1 . The curves for temperatures 320,365 and $400 \mathrm{~K}$ having similar shapes are not shown.

It is seen from Fig. 1 that the load changing at $T=300 \mathrm{~K}$ has a weak influence on the $\alpha_{d}$ value increase. However, as the sample is heated (curves 2-4) the same applied loads lead to the significant increase of the acoustic loss. It has been found that the experimental curves $\alpha_{d}(\sigma)$, the amplitudes of which increase with temperature rising, are shifting into the region of low statistic stresses. The effect of curves $\alpha_{d}(\sigma)$ shift can be explained qualitatively within the framework of the dislocation theory [9]. The dislocation absorption increase in the lower megahertz frequency band is related with the increase of the length $l(\sigma, T)$ of dislocation segments oscillating in the ultrasonic wave field. For the dislocation be separated from the stoppers it should overcome a potential barrier, the value of which is determined by the activation energy depending on the energy of dislocation binding with its pinning center. As the temperature increases the barrier value decreases and, as a result, the action of the external statistic load becomes more and more efficient.

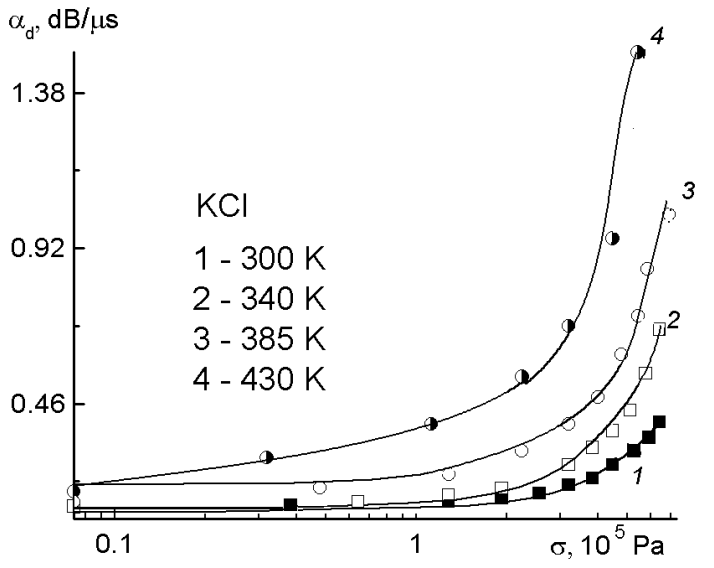

Fig. 1. Dislocation ultrasonic absorption in $\mathrm{KCl}$ as a function of the elastic statistic loading at different temperatures $T \mathrm{~K}: 1-300$, $2-340,33-385,4-430 ; f=7.5 \mathrm{MHz}$.

Under conditions of elastic statistic stresses the probability $W$ of the dislocation segment separation from one of the pinning stoppers, number of which $N=L / l$ ( $L$ is the Frank network dimension), is expressed in the following form [9]

$$
W(\sigma, T) \approx N \cdot \exp \left(-\frac{U(\sigma, T)}{k T}\right),
$$

where $U$ is activation energy of dislocation unpinning from the pinning centers which can be written as $U(\sigma, T)=U_{0}-(\Omega Y) \tau$. Here $U_{0}$ is energy of the dislocation binding with the pinning center in the absence of external stresses; $\tau=\Omega \cdot \sigma$ is the reduced shear stress provoking the dislocation slipping; $\Omega$ - orientation factor taking into account that the reduced shift stress in the slip plane is less than the applied stress; $\mathrm{Y}=b \cdot d \cdot l \quad$ - the activation volume [10], where $d \sim(1 \div 3) b$ [11] is distance of the effective dislocation binding with the stopper, $b$ - the Burger vector.

According to [5] increased probability of the dislocation separation from the stoppers under the external stress leads to change in the mean length of the dislocation segment that is written as

$$
l(\sigma, T)=L W+l(1-W) .
$$

As the dislocation resonance ascending branch attenuation is varying by the law $\alpha \sim l^{4}$ [9], it permits, on opinion of the authors of [5], to take, with close approximation, the expression 


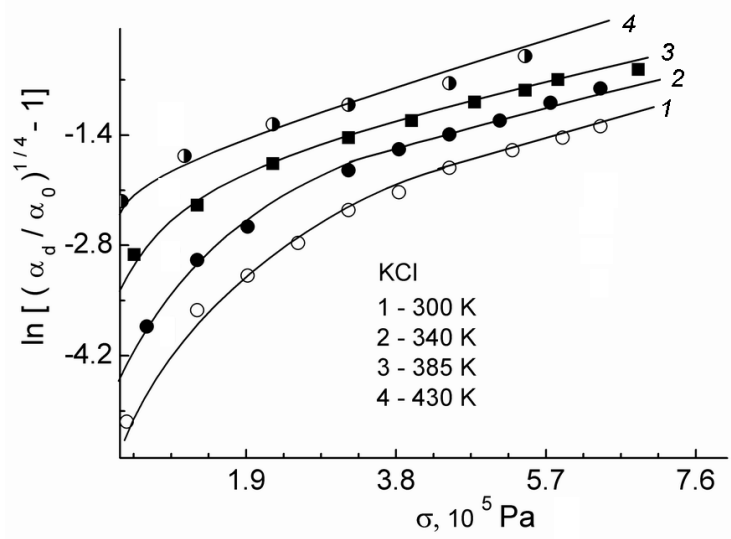

Fig. 2. Reduced dislocation absorption in $\mathrm{KCl}$ as a function of the external statistic loading: $1-4$ the same as in Fig. 1.

$$
\left(\frac{\alpha_{d}(\sigma)}{\alpha_{0}}\right)^{1 / 4} \approx \frac{l(\sigma)}{l} .
$$

Basing on equations (1)-(3) in [5] the relation between the measured dislocation absorption and the external statistic stress was obtained in the form

$$
\left(\frac{\alpha_{d}}{\alpha_{0}}\right)^{1 / 4}-1 \approx \frac{L^{2}}{l^{2}} \exp \left(\frac{U_{0}-\Omega b d l \sigma}{k T}\right) .
$$

Formula (4) determines relation between the dislocation absorption change under the homogeneous stress and the dislocation structure parameters. It has been derived under the assumption of catastrophic separation of the dislocation segments at values of $\sigma$ exceeding the conventional critical $\sigma_{k}$, when probability of the segment separation significantly exceeds the probability of the segment repinning. For experimental data processing it is convenient to present formula (4) in logarithmic form [5]

$$
\ln \left[\left(\frac{\alpha_{d}}{\alpha_{0}}\right)^{1 / 4}-1\right] \approx \ln \frac{L^{2}}{l^{2}}-\frac{U_{0}}{k T}+\frac{\Omega b d l \sigma}{k T} .
$$

According to (5) by writing the results shown in Fig. 1 in coordinates $\ln \left[\left(\alpha_{d} / \alpha_{0}\right)^{1 / 4}-1\right]-\sigma$ at the given temperature it is possible to determine the mean segment length by the slope $\operatorname{tg} \alpha=(\Omega b d l / k T)$. The results of the experimental data rearrangement are given in Fig. 2. It is seen that in each of the curves after reaching the stress $\sigma_{k}$ the linear sections appear from which the dependence $l(T)$ can be reproduced by the formula

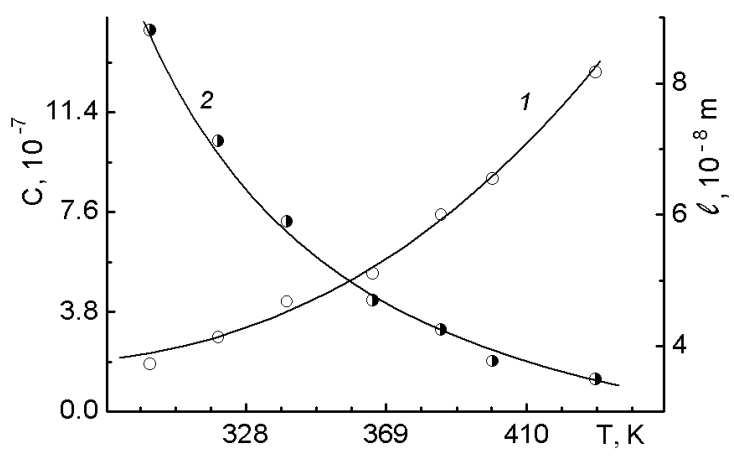

Fig. 3. Temperature dependences of the mean effective length of the dislocation segment 1 and impurity concentration on dislocations 2 in $\mathrm{KCl}$ crystals.

$$
l=\frac{k T \Delta \ln \left[\left(\frac{\alpha_{d}}{\alpha_{0}}\right)^{1 / 4}-1\right]}{\Omega b d \Delta \sigma} .
$$

Using the data given in Fig. 2 and values of $\Omega=0.42$ and $b=4.46 \cdot 10^{-10} \mathrm{~m}$, taken from [12, 13], $d=3 b[5], k=1.38 \cdot 10^{-23} \mathrm{~J} / \mathrm{K}$ dependence of the dislocation segment length $l(T)$ was obtained (see Fig. 3, curve 1$)$. It is evident that $l(T)$ increases with the temperature increasing, and taking into account equation (3) the dislocation absorption $\alpha_{d}$, should increase too, that is observed experimentally (see Fig. 1).

Very likely, that the dislocation segment length $l$ increasing with temperature is related with gradual decrease of the pinning center concentration $C$ on the dislocations. It is convenient to verify such an assumption with the use of the expression from [11]

$$
C=\frac{b \sigma_{k p}}{28 k T l N_{0}}
$$

Substituting in formula (7) the values of $b, \sigma_{k}$, $T, k$ and $N_{0}=8 / a^{3}$, where $a=6.295 \cdot 10^{-10} \mathrm{~m}$ [14] is the lattice constant, as well as, the results for $l(T)$, dependence $C(T)$ was obtained (see Fig. 3, curve 2). It is obvious, that the temperature increase promotes processes of the dislocation separation from the stoppers that leads to concentration $C(T)$ decrease and, subsequently, to $l(T)$ increase. Using equation [5]

$$
C \approx\left(\frac{\beta_{a}}{\beta_{m}}\right) \cdot C_{0} \cdot \exp \left(\frac{U_{0}-T\left(S_{m}-S_{a}\right)}{k T}\right),
$$


where $\beta_{a}$ and $\beta_{m}$ are the numbers of equivalent free positions of interstitials or substitutions in the unit cell of the dislocation atmosphere, $C_{0}$ - atomic fraction of impurity atoms in the matrix volume, $S_{a}$ and $S_{m}$ - oscillatory entropies of matrix atoms and dislocation atmosphere it is easy to find energy of the dislocation binding with the pinning center. By taking the logarithm of equation (8) we obtain

$$
\ln C \approx \ln \left[\left(\frac{\beta_{a}}{\beta_{m}}\right) \cdot C_{0}\right]-\frac{\left(S_{m}-S_{a}\right)}{k}+\frac{U_{0}}{k T} .
$$

It is seen from equation [9] that by plotting the dependence $\ln C-f(1 / T)$ it is easy to determine $U_{0}$ by the slope. Fig. 4 presents the dependence $\ln C-(1 / T)$ calculated with taking into account the curve $C(T)$. According to recommendations of [6] by plotting the linear dependence we oriented ourselves onto the points related to the high-temperature regions where the mechanisms of dislocation thermal unpinning from the impurity atoms prevail over purely mechanical separation. After determination of the temperature behavior of the indicated line we have found value of the energy of the dislocation binding with the stoppers $U_{0}$ $\sim 0.35 \mathrm{eV}$ that is in good agreement with the results of $[5-7,11]$. Then, using the found value of $U_{0}$, curve $l(T)$ and the values of intercepts on Y-axis (Fig. 2) we have determined by formula (5) an average size of the dislocation cell $L$. It has been established that the quantity $L$ does not depend on the temperature and its average value is $4.2 \cdot 10^{-6} \mathrm{~m}$, that is in good accord with the data of $[9,12,14]$.

\section{Conclusions}

The acoustic impulse method was applied to investigate, in the temperature range from 300 to $430 \mathrm{~K}$ at $7.5 \mathrm{MGz}$ frequency, the dislocation absorption $\alpha_{d}(\sigma)$ in $\mathrm{KCl}$ crystals as a function of the statistic load in the quasi-elastic strain range. It has been found that at $T=300 \mathrm{~K}$ the loading change has a weak effect on the quantity $\alpha_{d}$ increase. However, after the rise in temperature the same loads lead to significant acoustic loss increasing. The effect of experimental curves $\alpha_{d}(\sigma)$ displacement was observed, i.e. by increasing their amplitudes, they were shifting into the region of low statistic stresses.

As a result of the experimental data processing within the framework of the

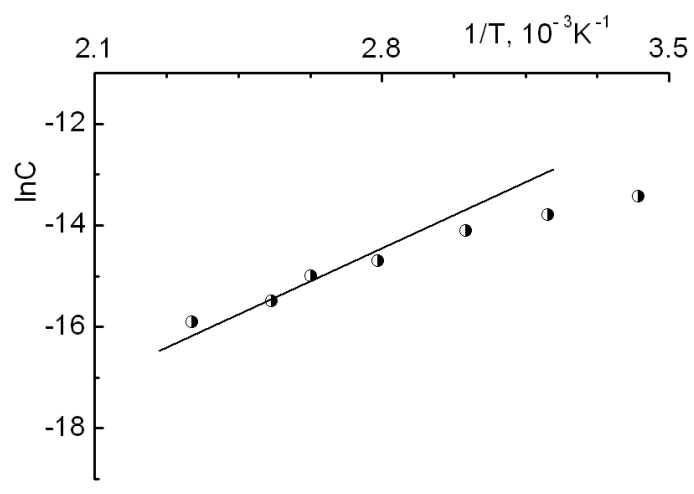

Fig. 4. Temperature dependence of the pinning centers on dislocations in $\mathrm{KCl}$ crystals.

known theories the temperature dependences of the dislocation segment length $l(T)$ and the point pinning center concentration on dislocations $C(T)$ were determined. It is shown that the temperature increase under the stresses $\sigma<\sigma_{t} \quad\left(\sigma_{t}\right.$ denote the yield strength of a crystal) leads to the intensive dislocation unpinning. Consequently, concentration of the stoppers controlling the dislocation motion sharply decreases and the effective length of oscillating dislocation segments increases.

The value of energy of impurity atom binding with the dislocation is was calculated, which equals about $0.35 \mathrm{eV}$ for $\mathrm{KCl}$ crystal. Besides, it has been found that the quantity $L$, being characteristic of the dislocation cell, does not depend on the temperature and its average value is of about $4.2 \cdot 10^{-6} \mathrm{~m}$. Analysis has shown that the values of mentioned dislocation characteristics are in close agreement with the theoretical estimates, as well as, with the experimental data obtained by the same method for ion crystals $\mathrm{Csl}$ and $\mathrm{KBr}$.

\section{References}

1. S.P.Nikanorov, B.K.Kardachev, Elasticity and Dislocation Inelasticity of Crystals, Nauka, Moscow (1958) [in Russian].

2. M.A.Krishtal, S.A.Golovin, Internal Friction and Structure of Metals, Metallurgiya, Moscow (1976) [in Russian].

3. V.L.Indenbom, V.M.Chernov, in: Mechanisms of Relaxation Phenomena in Solids, Nauka, Moscow (1972), p.87 [in Russian].

4. V.I.Startsev, V.Ya.Illichov, V.V.Pustovalov, Plasticity and Strength of Metals and Alloys at Low Temperatures, Metallurgiya, Moscow (1975) [in Russian].

5. M.A.Krishtal, S.A.Golovin, I.V.Troitskij, Fizika Metallov i Metallovedenie, 35, 632 (1973). 
6. A.M.Petchenko, Fizika Tverd. Tela, 33, 1541 (1991).

7. G.A.Petchenko, Functional Materials, 8, 483 (2001).

8. R.Truell, Ch.Elbaum, B.Chik, Ultrasound Methods in Solid-state Phisics, Mir, Moscow (1978) [in Russian]

9. A.Granato, K.Lucke, J.Appl.Phys., 27, 583 (1956).

10. J.Hirth, I.Lothe, Theory of Dislocation, Atomizdat, Moscow (1972) [in Russian].
11. A.H.Cottrell, Dislocations and Plastic Flow of Crystals, GosNTI Lit. po Chornym i Tsvetnym Metallam, Moscow (1958) [in Russian].

12. V.M.Andronov, A.M.Petchenko, A.I.Startsev, Akusticheskij Zh., 21, 502 (1975).

13. A.M.Petchenko, Functional Materials, 7, 94 (2000).

14. A.M.Petchenko, G.A.Petchenko, Ukrainian $J$. Physics, 55, 716 (2010). 